\title{
"QUE LAS RIQUEZAS DEL MUNDO PARECIAN ESTAR ALLI CIFRADAS': CATHERINE OF BRAGANZA'S WEDDING FESTIVITIES IN THE CONTEXT OF THE PORTUGUESE RESTORATION (1661-1662)
}

\author{
Susana Varela Flor \\ Instituto de História da Arte. Universidade Nova de Lisboa
}

The aim of this paper is to study Catherine of Braganza's wedding festivities and to frame them in the historical context of the dissolution of the Spanish-Portuguese Union in 1640. In order to better understand one of the models that served as inspiration for these ceremonies, the focus of the analysis will be centred on the wedding between Maria Theresa of Spain and Louis XIV of France, as well as on the pro-Restoration discourse used by the House of Braganza.

Key words: Baroque Festivals; Catherine of Braganza; Restoration; Portrait; Dirck Stoop.

\section{“QUE LAS RIQUEZAS DEL MUNDO PARECIAN ESTAR ALLI CIFRADAS”: LOS FESTEJOS DE BODA DE CATALINA DE BRAGANZA EN EL CONTEXTO DE LA RESTAURACIÓN PORTUGUESA (1661-1662)}

El propósito de este trabajo es el estudio de los festejos de boda de Catalina de Braganza y de enmarcarlos en el contexto histórico de la disolución de la unión Hispano-Portuguesa en 1640. A fin de comprender mejor uno de los modelos que sirvió de inspiración para estas ceremonias, el enfoque del análisis se centra en la boda entre $\mathrm{M}^{\mathrm{a}}$ Teresa de España y Louis XIV de Francia, y en el discurso a favor de la restauración utilizado por la casa de Braganza.

Palabras clave: Festivales barrocos; Catalina de Braganza; Restauración; Retrato; Dirck Stoop.

\footnotetext{
${ }^{1}$ Susana Varela Flor is a full member of IHA-FCSH/NOVA as a post-doctoral fellowship (SFRH/BPD/101741/2014) funded by FCT (Portuguese national funding agency for science, research and techology) with the participation of the European Social Fund and National funds from the Portuguese Government. This article was translated by Hanna PietaCândido in the framework of the research project "DigiTile Library: Tiles and Ceramics on line" - PTDC/EATEAT/117315/2010. For more information on Catherine of Braganza, see bibliography. I am gratefully indebted to Lisbon City Museum [Museu da Cidade]; to Art Library of Calouste Gulbenkian Foundation and Universidade Autónoma de Lisboa for the images copyrights.
} 


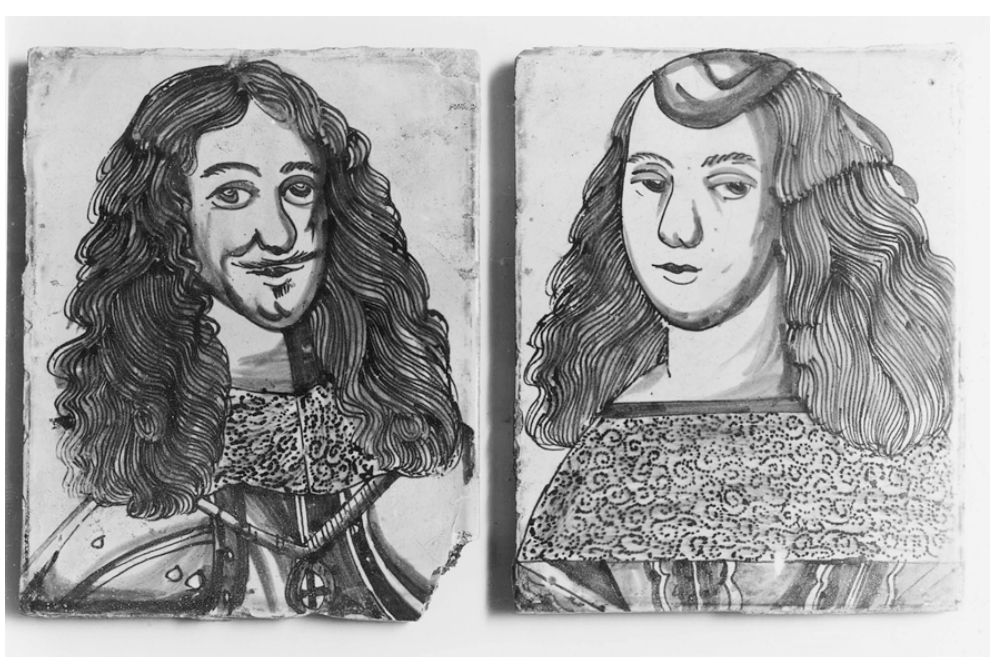

Fig. 1. Portraits of Charles II and Catherine of Braganza, c. 1662 , Art Library Calouste Gulbenkian Foundation. (CFT009.1450.ic).

\section{Catherine of Braganza, Queen of England (1638-1705)}

The third daughter of Dukes of Braganza was born in 1638 on St. Catharine's day and was hence named after this martyred virgin ${ }^{1}$ (fig. 1). Aged two, she moved to Lisbon with her mother, Luisa de Guzmán (1613-1666) from the House of Medina Sidonia, and was raised in the Ribeira Palace. There, under the supervision of her mother, she received a mixture of court and convent education. Years later, in a letter to the Duchess of York -Anne Hyde (1637-1671)-, Luisa de Guzmán explained that her daughter had been raised in a sheltered way, a more useful education than pleasant, but she demonstrated the affection for the Portuguese lifestyle (con encogimento de portuguesa más util que agradable mas tanbien quiere como portuguesa $)^{2}$.

From early on, the first Infantes of the new dynasty, i.e., Teodósio (1634-1653), Joana (16351653) and Catharine, had played strategic roles in political alliances in the European context. However, due to the premature death of Teodósio and Joana, the faith of the Portuguese nation had been placed in the hands of the youngest daughter of the Portuguese King. Thus, when she turned 22, Catherine's life suffered profound alterations. In July 1661, she was entitled Queen of England, taking on the duties inherent to this position: learning English language, representing the British Crown in the official acts and familiarizing herself with the new culture. The latter task included taking on new clothing and footwear, which, reportedly, resulted in strains and bruising. However, not even this seemed to have lessened her desire to leave Portugal ${ }^{3}$.

On 23rd June 1661, Francisco de Mello e Torres (c.1610-1667), future Marquis of Sande, signed in London the Whitehall Treaty on behalf of the Portuguese Crown. The signing of this peace and trade alliance proved to be an important turning point in the political role that Portugal played in Europe after gaining its sovereignty from Spain. Accordingly, the marriage between Catherine of Braganza and Charles II of England (1630-1685) was considered as a great diplomatic victory of the House of Braganza in the post-Restoration period (fig. 2).

\footnotetext{
${ }^{2}$ DGLAB/TT, Colecção de São Vicente, Livro 20, fl.312.

${ }^{3}$ Bodleian Library, Carte Papers, Ms.73, fls. 598 e 608: “... the accident to Queen Catherine's foot occurred in the course of her Majesty's attempt 'to go currently, in English shoes with high heels'. Adds that she is reported to have said 'Nothing can damp her desire to be in England...'.
}

Arch. esp. arte, LXXXVIII, 350, ABRIL-JUNIO 2015, 141-156 ISSN: 0004-0428, eISSN: 1988-8511, doi: 10.3989/aearte.2015.09 


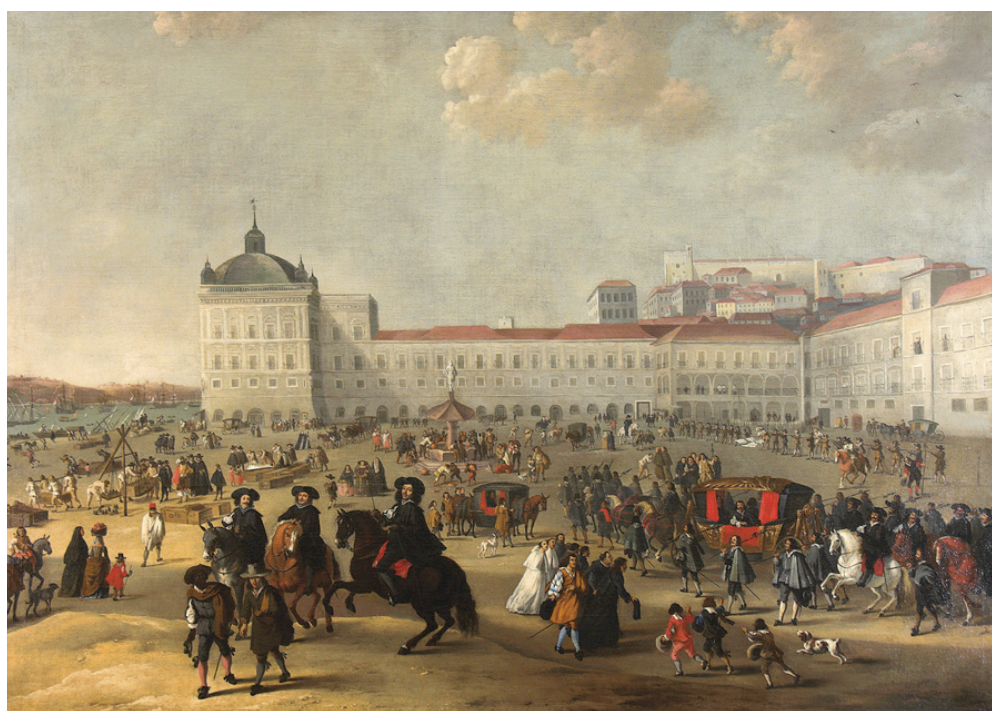

Fig. 2. Dirck Stoop, The Terreiro do Paço, 1662, Museu da Cidade (Lisboa).

\section{Wedding Celebrations (October/November 1661)}

In May 1661, Charles II's decision to marry Catherine of Braganza was met in Portugal with great relief. As soon as the news of their engagement had been announced, the Portuguese Crown started the preparations for the wedding festivities. As a consequence, as early as in August the celebrations of the Anglo-Portuguese union took place all over Portugal. Immediate reactions, in the form of gun salutes, firework and flare displays, were noticeable both in and outside the capital, particularly along the Spanish border. This is reported in a letter by Martim Correia da Silva, Governor of the Algarve: "once the happy cause is announced, the squares of Castro Marim and Alcoutim, close to the enemy's border, should echo with gun salvas, to lift people's spirits"4.

These reactions, as well as many others occurring in the following months, are also described in a published account named "Relacion de las fiestas que se hizieron en Lisboa, con la nueva del casamiento de la Serenissima Infanta de Portugal Doña Catalina..." and attributed to António de Sousa de Macedo (1606-1682), a man of great erudition, former Portuguese diplomat in England and, at that time, Secretary of State at the court of Afonso VI

The aforementioned work, together with a comparative analysis of written and iconographic sources, provides useful information for a study of the celebrations of the royal wedding of Catherine of Braganza and Charles II of England. The streets of Lisbon are reported to have spontaneously filled with fireworks, music and crowds cheering victory. At the very same time, the royal court is said to have organized religious festivities, which included a procession with the participation of the Chapter of Lisbon Cathedral, religious orders and the Senate of the City Regiment ${ }^{6}$. In the Royal Chapel, in turn, the event was celebrated with a Te Deum, "haciendo assy el fundamento en Dios, en quien se esperan desta aliança las mejores resultas para su seruicio." Finally,

\footnotetext{
${ }^{4}$ Carta de Martim Correia da Silva para Sua Magestade dando notícias das luminárias, Biblioteca da Ajuda, Ms. 51-IX-1, fl. 205v.

${ }^{5}$ Macedo, 1662.

${ }^{6}$ Oliveira, 1893: 287.
}

Arch. esp. arte, LXXXVIII, 350, ABRIL-JUNIO 2015, 141-156 ISSN: 0004-0428, eISSN: 1988-8511, doi: 10.3989/aearte.2015.09 


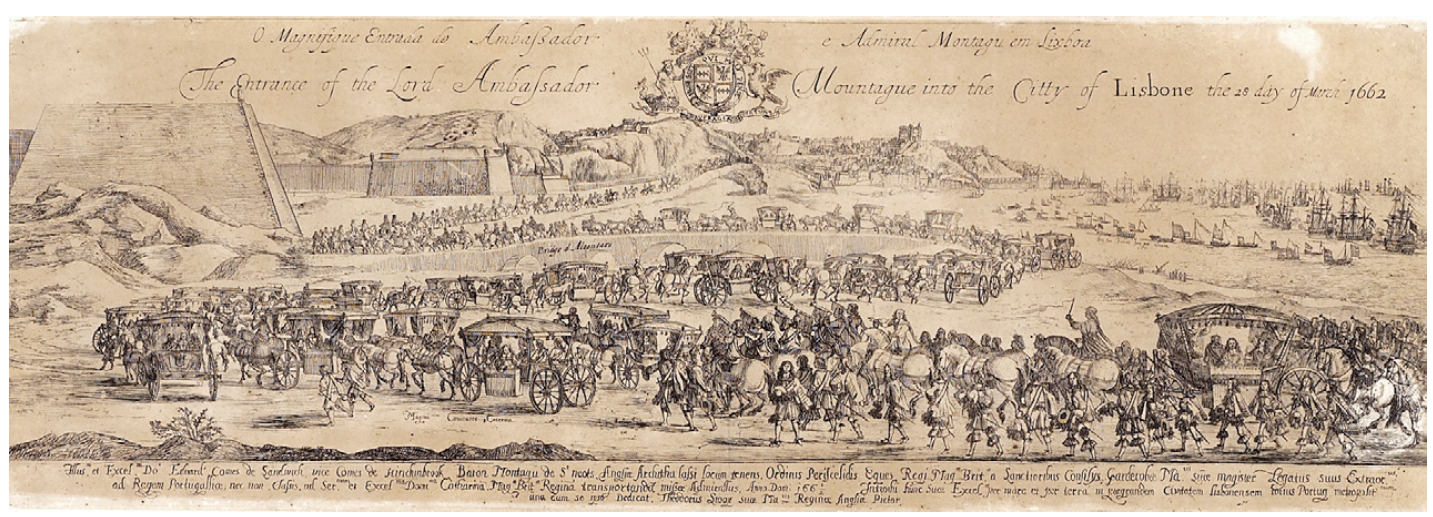

Fig. 3. Dirck Stoop, Montagu's entry in Lisbon 28th of March 1662, 1662, Museu da Cidade (Lisboa).

in his work Macedo refers to "danças e aparatos usados nas maiores solenidades", thus pointing to the coexistence of the sacred and the profane ${ }^{7}$.

The English ambassadors arrived in Lisbon in September 1661 (fig. 3). The first to disembark was Edward Montagu (1625-1672), i.e., Ambassador Extraordinary and Earl of Sandwich. He was followed by Sir Richard Fanshaw (1608-1666), who arrived in Lisbon a few days later. Among the high-profile members of Montagu's entourage one should mention the painter Dirck van der Stoop, also known as Dirck Stoop (c. 1610-1680), who produced two series of etchings, with a total of sixteen iconographic depictions of wedding celebrations. The first series portrays the festivities acclaiming the royal marriage ${ }^{8}$ and the second one some panoramic views of Lisbon'.

On 10th and 17th of October two bullfights were organized as part of the official celebrations. As regards the wooden seating for the audience (built at Terreiro do Paço) and the bullfighters' outfits, each event required distinct preparations (fig. 4).

Among numerous texts praising these festivities, including the ones produced by António de Sousa de Macedo, of particular relevance seem to be the works entitled Relacion das Fiestas and the Festas Reays na Corte de Lisboa. These were composed by a group of forcados, including one known by the name of Aonio, who, as argued by Edgar Prestage, was António de Sousa de Macedo himself ${ }^{10}$.

\footnotetext{
7 "Showing faith in God, in the hope of receiving great awards for their services", (...) "dances and pompous spectacles accompanying solemn ceremonies". Cf. Macedo, 1662: 21 and 22.

${ }^{8}$ As far as the first series is concerned, it includes eight engravings: "O Magnifique Entrada do Ambassador e Admiral Montagu em Lisboa"; "Touros Reays nas Festas do Cazamento da Rainha da Gran Bretanha em Lisboa 1661"; "Reais Festas e Arcos Triunfais que se fizerão na Partida da Sereníssima Donna Catarina Raynha da Gram Bretanha"; "Vista de Lisboa e como a Rainha da grã Bretanha se Embarquo para Inglaterra"; "O chegado duque Jorck no Cannal entre o froto d'Englaterra"; "Dis Embarcação da Rainha da Gran Bretan em Portsmuit"; "Passage del Rey de gran Bretanha Carolo II e o Rainha Dona Catarina de Portsmuit per a Hamton-Court" and "Entrada publica que a S.ma Rainha da G.B. fés na cidade de Londres e como magnificamente foi recebida da noboesa e povo della em 2 de Sept. 1662". For more information on these etchings, see Soares, 1954: 106-110. Concerning the first engraving of the series, we should mention that it refers to the second arrival to Lisbon after the journey to Tangier and not to the one taking place in 1661.

9 "A vista geral de Lisboa", "A Torre e entrada da Barra de Bellem"; "O Convento de St. Hierónimo em Bellem"; "a vista de Santo Amaro e prospectiva do lugar de Bellem"; "o Palácio do Infante D. Pedro em o Corpus Sancto em Lisboa"; "o Palácio Real de Lisboa"; "a vista do Convento da Madre de Deus" e "o Rio Tejo e a Cidade de Lisboa".

${ }^{10}$ Macedo (Aonio), 1661. See also Prestage, 1914: 325.
} 


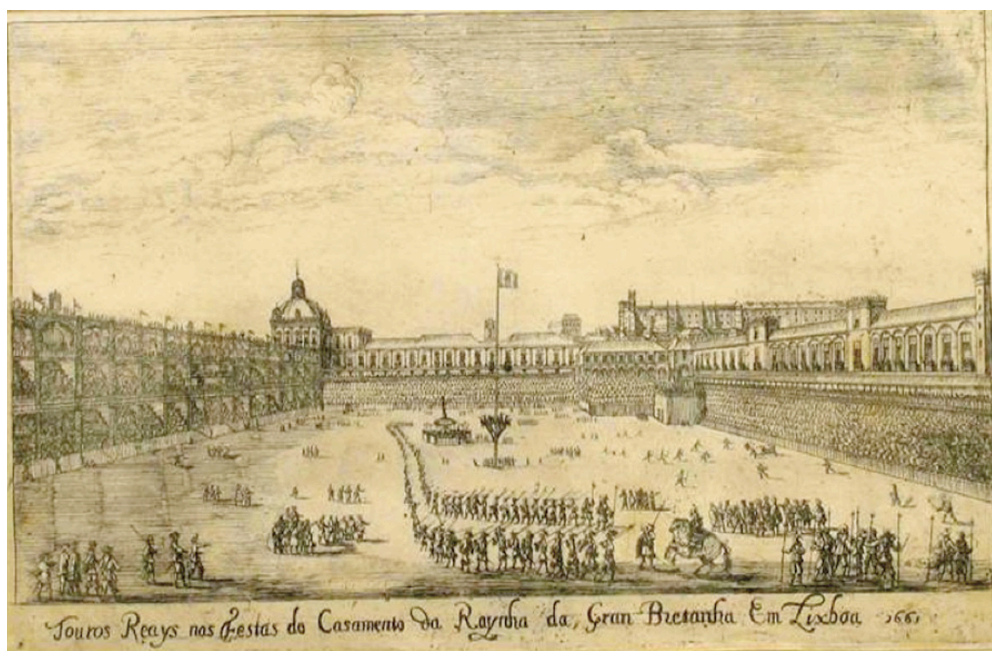

Fig. 4. Dirck Stoop, Bullfight, 1661, Museu da Cidade (Lisboa).

When viewed from the standpoint of nationalistic rhetoric, the above mentioned bullfights can be considered as a demonstration of power, boldness, joy and wealth of the Portuguese nation that was giving away the hand of its Princess in marriage ${ }^{11}$. This perspective is clear in the aforementioned texts. Firstly, the poets Izandro and Aonio express annoyance with the fact that the English ambassador, the Commissioner of the States of Holland and a representative of the French Crown attended the spectacle ${ }^{12}$.

Secondly, the audience, consisting of high-ranking officials, ministers, ladies, lords, knights and crowds of common people, is compared to mundo abreviado [the world in miniature], admiring the courage of the Portuguese: "Para la fiesta de toros se arboló en médio de la Plaza de Palacio una vandera de doze varas de damasco blanco con franjones de oro, y en ella las armas Reales de Portugal.(...) Eran todos de una altura, y correspondencia en sus rexas bien pintadas: cubiertos de sedas, telas, brocados, y brodados de plata y oro."13

Among the bullfighting events (such as the Royal Guard parade, concerts and bullfighting on foot) special prominence was given to the spectacle performed by riders on horseback, with the participation of three noblemen of very high rank: Luis Lobo da Silveira (Count of Sarzedas), João Mascarenhas (Count of Torre and, later on, First Marquis of Fronteira) as well as João de Castro (Lord of Paul de Boquilobo).

The next item on the calendar of wedding celebrations was the "Triumph of Concord" or the "Royal Triumph", accompanied by a text entitled Quarto dia do triunfo dos animais [The fourth day of animal triumph] and composed, according to Diogo Barbosa Machado, especially for this occasion by Berardo Companheiro da Bandeirinha (most probably the pseudonym of António

${ }^{11}$ Cardim, 2008: 185-206.

12 Cabral, 1661: 281-288.

13 "During the bull-fighting festivities, twelve flags on a white damask cloth with golden fringes and royal arms of Portugal were put in the middle of the Palace Arena (...) They were all of the same height and size and with rich decorations: covered with silks, linens, brocades and silver and golden embroideries." Cf. Macedo, 1662: 16. The Earl of Sandwich also reported on these festivities: "This day I went to Lisbon to see the huego de Toro, taking place on a square place before the King's Palace, built on the two other sides with scaffolds three-storey high hung with tapestry and carpets rich according to the quality of the noblemen and others to whom they belonged...”. Anderson, $1929: 100$.

Arch. esp. arte, LXXXVIII, 350, ABRIL-JUNIO 2015, 141-156

ISSN: 0004-0428, eISSN: 1988-8511, doi: 10.3989/aearte.2015.09 
Lopes Cabral). The already mentioned Relacion de las Fiestas also makes reference to this event, suggesting that it was awaited with high expectations ${ }^{14}$. Regrettably, none of Dirck Stoop's etchings portrays this event, given that during this period the artist is known to have accompanied Montagu to Tangier. The period between January and March 1662 had thus been marked by preparations for the arrival of Montagu's naval fleet and, to a certain extent, for the celebrations and the subsequent departure of the Queen.

Montagu's armada returned from Tangier on 13th March 1662. It was first anchored in the Fort of São Julião da Barra and, afterwards, in front of The Hieronymite Monastery of Santa Maria of Belém. In all likelihood the Dutch artist took advantage of this situation in order to produce sketches of some of the principal monuments sited in this district, such as the Hieronymite Monastery, the Tower of Belém and the more distant Chapel of Santo Amaro (figs. 5, 6 and 7).

\section{Wedding Celebrations (April 1662)}

According to the records published by Eduardo Freire de Oliveira and concerning the celebrations taking place on 23rd of April 1662, the Secretary of Internal Affairs, by order of King Afonso VI, nominated officials in charge of carrying out the protocol for this specific day ${ }^{15}$. Thus, as registered in Relacion de las Fiestas, on 22nd of April, on the eve of Catherine's departure to England, the Regiment of the City of Lisbon organized a horseback masquerade. This widely attended event took place on Terreiro do Paço and spread across the main arteries of Lisbon. The choice of date was deliberate, as 23rd of April had been celebrated as Saint George's day (a Christian knight and the patron saint of both Portugal and England). The interior of Ribeira Palace is said to have been filled with courtiers, dressed with pomp and bidding their farewell to Queen Mother and Queen of England, boasting such luxury that "las riquezas del Mundo parecian estar alli cifradas."16

Every move of the Queen, from exiting the Ribeira Palace to boarding the Royal Charles vessel, had been stipulated in the embarkation protocol ${ }^{17}$.

A comparison of different written testimonies indicates that twelve structures and wooden arches, put up by the city's master builders, were spread over the streets of Lisbon. It also suggests that the route the royal couple travelled started at the Arch of Luís César de Meneses, included Tanoaria, Calcetaria, Rua Nova and Padaria and finished at the Lisbon Cathedral. When erecting the arches, the master builders were assisted by decorators, whose role was to embellish the streets "with columns, trophies, fountains and groves, at their very best effort." 18

By the same time, the Senate of Lisbon arranged for the workmen from Armazéns, Casa das Obras, Casa dos Contos, Alfândega and Ribeira das Naus to help with the decorating tasks. For instance, as regards the ornamentations of the part of the route stretching between the gates of the Armazéns and the Arch, Provider Luis Cézar de Menezes himself paid for the decorations spanning up to the courtyards. The street sellers covered the costs of decorating the remaining parts of this stretch.

Furthermore, the English had been in charge of decorating the Arch of the English Nation, with the statue of Saint George on top. For their part, the Germans erected a magnificent arch at Terreiro do Paço.

\footnotetext{
${ }^{14}$ Cabral, 1661.

${ }^{15}$ Oliveira, 1893: 286-287, 336-339. Tojal, 1716. For information on wedding festivities see also: Santarém, 184269: 236-257; Brasão, 1939: 269-286; Vidal, 1940: 1-7; Costa, 1956: 3-7.

16 "it seems to contain the world's greatest treasures". Cf. Macedo, 1662: 29v.

${ }_{17}$ Biblioteca da Ajuda, Ms 51-VIII-25, no 121, fl.231.

${ }^{18}$ Brasão, 1939: 269-286.
} 

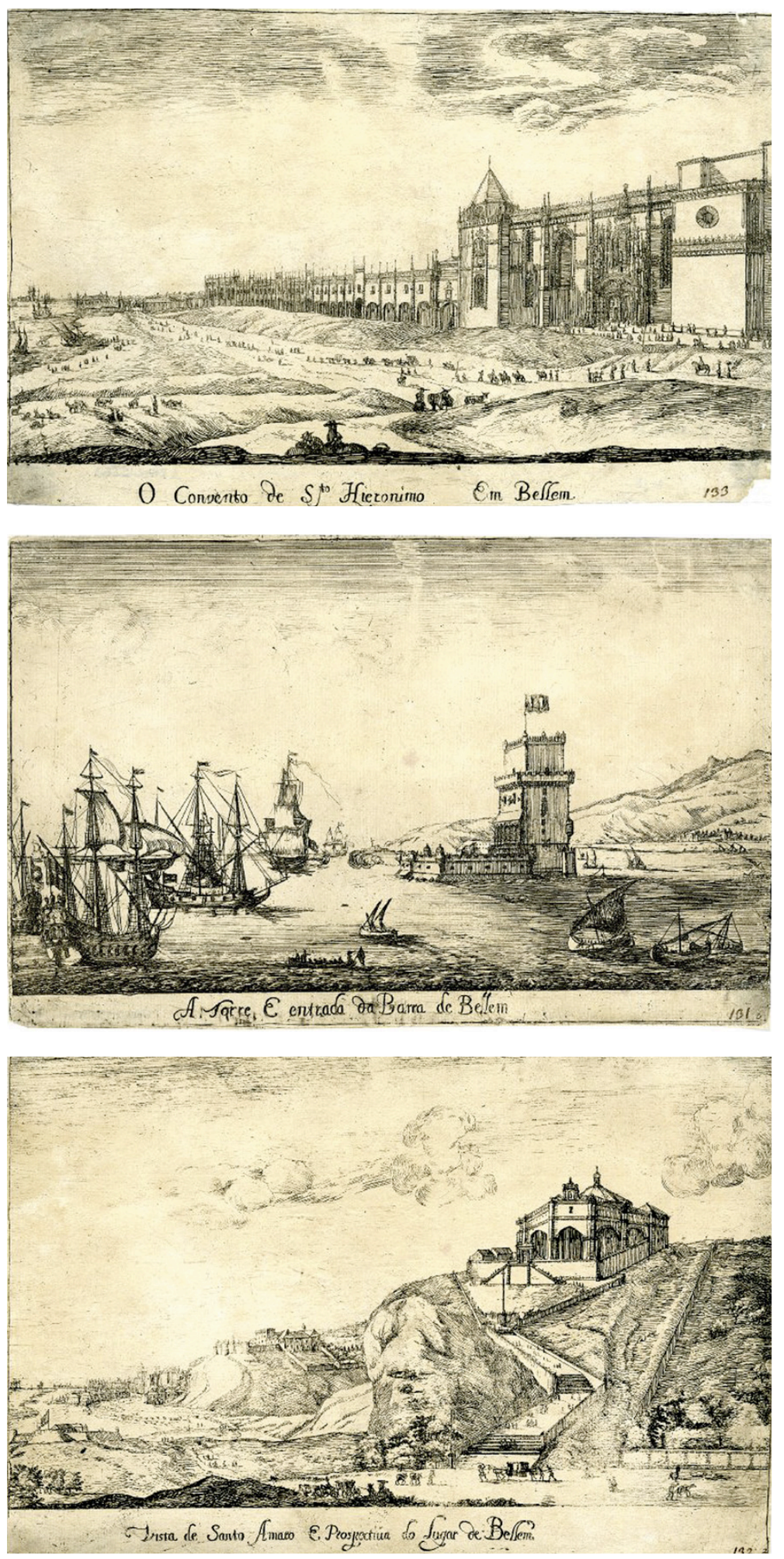

Fig. 5. Dirck Stoop, The Monastery of Belém, 1661, Museu da Cidade (Lisboa).

Fig. 6. Dirck Stoop, Belém Tower, 1661, Museu da Cidade (Lisboa).

Fig. 7. Dirck Stoop,

Saint Amaro Chapel, 1661, Museu da Cidade (Lisboa).

Arch. esp. arte, LXXXVIII, 350, ABRIL-JUNIO 2015, 141-156 ISSN: 0004-0428, eISSN: 1988-8511, doi: 10.3989/aearte.2015.09 
The analysis of different bibliographical sources reveals that the arches spread across the city featured representations of all the rulers of Portugal, including Count Dom Henrique and Constable Nuno Álvares Pereira. Altogether, the arches featured representations of the first seventeen Kings of Portugal, the last one being that of Cardinal Henry I. In this manner: "the royal arches will recall the victories of Portuguese sovereigns as well as celebrated actions of the Portuguese nation." ${ }^{, 19}$ These propagandistic representations of Portuguese key historical figures coexisted with the depictions of Catherine of Braganza and King Charles II. Street ornaments were subject to a rigorous control, as the "Embarkation Protocol" included specific indications with regard to the standardization of decorative elements (such as tapestries, silk bedspreads, tapes interwoven with golden and silver threads, paintings, etc). According to Sousa de Macedo, no words could do justice to "adorno, y concierto de las calles, estauan todas, siendo muchas, y largas, cubiertas las casas, no solo de buenos tapizes, y colgduras de ricas telas y sedas, mas aun sobre esto tan brincadas de quadros, guarniciones, passamanos, rendas de plata y oro, que toda aquella parte de la Ciudad... parecia en el adorno una Iglesia... ."20

The entourage, accompanied by militia units, dancers, revelry, musicians (trumbets, shawms, minstrels) as well as constant tolling of church and convent bells, followed the route through the streets of Lisbon. The celebrations were of such importance that the Secretary of State himself stipulated the way in which the entourage and the royal route was organized ${ }^{21}$.

Upon entering the Lisbon Cathedral, Catherine and her brother, D. Afonso VI, were welcomed by the Chapter and kissed the relics of the True Cross. From the large square in front of the Cathedral until the high altar the King, together with infantry units, escorted the Queen of England. Inside the Cathedral they were hailed with "choirs of sweet and harmonious Orphic voices.",22

The English guests did not participate in the catholic ceremony. Instead, they followed the Count of Ponte to the cloister. There, to quote the expression used by Macedo, they were entertained with a beautiful piece (hermosa pieça) of embroidery, recounting the story of the 1640 Restoration. Most likely, the tapestry, strategically placed at the very end of the royal route, featured a depiction of King João IV: "Mello is asked a question, with a raised finger: 'which King is presented on this portrait?' Looking at the venerated vault, Mello replies: 'here, marked with a distinct colour, you can see the rarest acclamation in history: Spanish mischief and the glory of this Empire." $" 23$

By two o'clock in the afternoon, the entourage returned to the Terreiro do Paço, described as a grand and magnificent square (plaza grandiosa e real), where their carriage passed through "una calle de verduras y flores, echa en arco de una, y outra parte, y en el médio un arco bien magnifico, que los Alemanes hizieron." 24

They were greeted with gun salutes by militia detachments and entered the gardens of the Ribeira Palace directly through the newly erected gate (called Porta da Campaínha) giving access to the pier at the Ribeira das Naus.

19 Tojal, 1716: 79

20 "The adornment and harmonious order of the streets, the numerous and large statutes, the houses decorated not only with beautiful tapestries, linens and silks but also with paintings, curtains tapes, silver and golden laces; all this made this part of the city (...) similar to a church adornment." Macedo, 1662: 30.

${ }^{21}$ Cf. Biblioteca da Ajuda, Ms. 51-IX-32.

${ }^{22}$ Tojal, 1716: 92.

${ }^{23}$ Tojal, 1716: 94. The celebration protocol mentions four Portuguese who accompanied the English guests. It is possible that António de Sousa Macedo was one them, especially if we consider his English connections and the fact that he was very well informed about the exhibits presented to Charles II' entourage.

24 "a street carpeted with plants and flowers, with arches on both sides and, in the middle, a magnificent arch erected by the Germans “. Macedo, 1662: 30v.

Arch. esp. arte, LXXXVIII, 350, ABRIL-JUNIO 2015, 141-156 ISSN: 0004-0428, eISSN: 1988-8511, doi: 10.3989/aearte.2015.09 


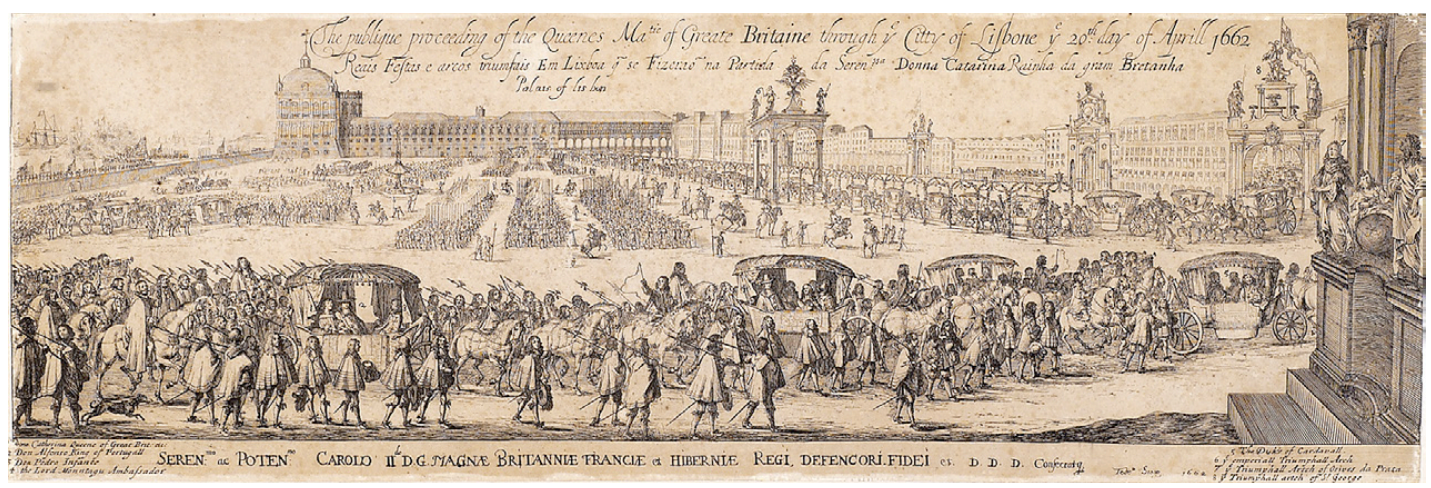

Fig. 8. Dirck Stoop, Royal festivities and triumphal arches, 1662, Museu da Cidade (Lisboa).

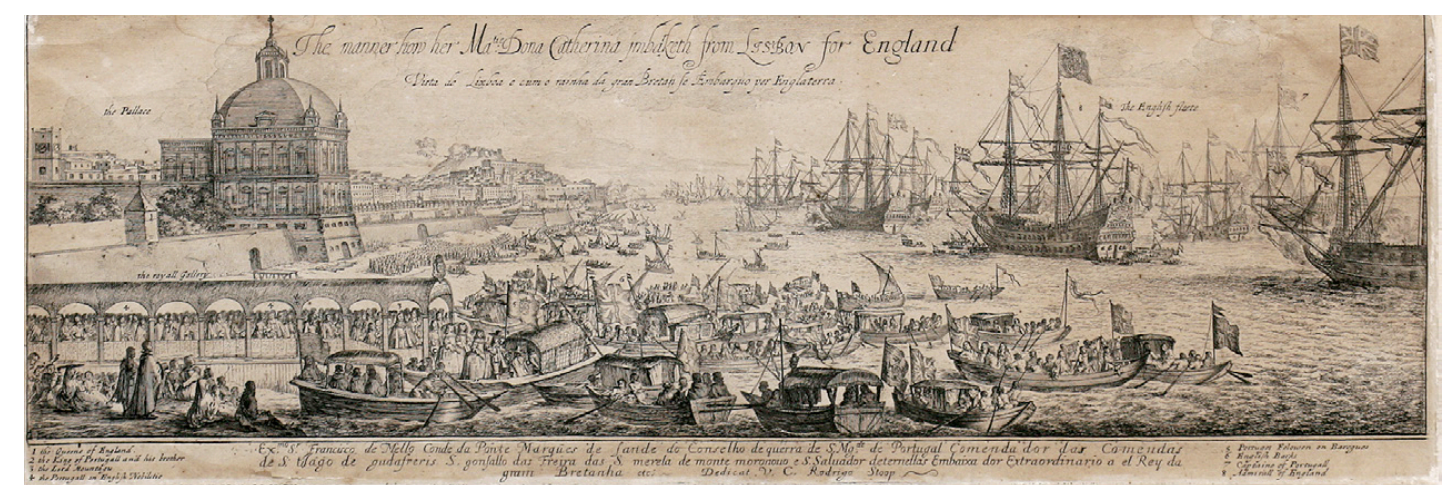

Fig. 9. Dirck Stoop, Vista de Lisboa e como a Rainha da Grã-Bretanha se embarcou para Inglaterra, 1662 , Museu da Cidade (Lisboa).

In the foreground of Stoop's etchings one can observe the royal carriage with Catharine of Braganza, Afonso VI (sitting by her side) and Pedro (sitting in front of the Queen) (fig. 8). Similarly to the rest of the entourage, the carriage was surrounded by militia units who protected the Queen from the crowds eager to attend this highly important event.

At the gardens of the Ribeira Palace, one could find an arch sponsored by the Provider of the Casa da Índia, as well as a painting and a statue (described by Pedro de Azevedo Tojal) ${ }^{25}$.

The crossing of the Ribeira das Naus pier was followed by a protocolary farewell conducted by high officials of the Court (fig. 9). The embarkation itself was accompanied by tolling bells, gun salvos fired by the English naval fleet, artillery salutes echoing from Saint George's Castle and music played on the numerous vessels decorated specially for the occasion by order of the City Senate. When depicting the embarkation of the Portuguese entourage, with the imposing Saint George's Castle in the background, the artist gave prominence to the movement of vessels floating on the Tagus. This scenery seems to be in line with the description offered by Macedo: "en llegando al baxel se abatió la vandera ordinária, que ténia de los colores Inglezes; $y$ en su lugar enarboló un estandarte Real."26

\footnotetext{
${ }^{25}$ Tojal, 1716: 106. Borges, 1986: 14-15, 25-25.

26 "an ordinary flag with Spanish colours was taken out of the vessel and replaced with a royal banner." Macedo, 1662: $31 \mathrm{v}$.
}

Arch. esp. arte, LXXXVIII, 350, ABRIL-JUNIO 2015, 141-156 ISSN: 0004-0428, eISSN: 1988-8511, doi: 10.3989/aearte.2015.09 
During the night activities, when the Queen was already aboard the vessel, the crowds could attend a performance similar to the battle of the four elements, with artillery fire spreading over the Tagus. The expenditures were supported by both the Senate and the States of Holland, as the latter had offered to sponsor an event of this kind ${ }^{27}$. The festivities finished with a calming music played by the musicians of the Royal Chamber.

\section{Maria Theresa of Spain wedding celebrations as a model of matrimonial festivities}

Our research, aiming at identifying models serving as inspiration for the 1661-1662 celebrations, suggests that the pro-Restoration discourse that dominated the festivities connected to Catherine of Braganza's wedding (clearly visible, for instance, in the already mentioned work Relacion de las fiestas) had one specific receiver in mind: the neighbouring Spain. A close analysis of bibliographical sources makes it possible to consider the 1660 wedding of Maria Theresa of Austria (1638-1683) with Louis XIV of France (1638-1715) as a model that served as inspiration for the wedding of the daughter of Portugal ${ }^{28}$.

The Treaty of the Pyrenees, signed between France and Spain, consolidated the wedding between the royal couple. It was ratified in November 1659 and in April 1660 Maria Theresa of Austria, together with her father Philip IV of Spain and a vast entourage, left for the Pheasant Island (close to the town of Fuenterrabía, near the French border) ${ }^{29}$.

The analysis of the festivities related to the wedding of the Spanish Princess and the French monarch led to the identification of a number of historical and iconographic similarities, some of which will be discussed in what follows. First and foremost, as in the case of Catherine of Braganza's wedding, Maria Theresa's wedding ceremonies had also been duly described, this time in a text authored by Leonardo Castillo, a representative of the Spanish Secretary of State. The text, entitled "Viage del Rey N. S. D. Phelipe IV ala Frontera de Francia. Desposorio de la Serenissima Sr. Infante de España y solemne iuramento de la Paz", later published in 1667 and containing engravings by Pedro de Vilafranca (1632-1684), makes reference to the splendour of the " $u n$ soberano matrimónio que volvió a enlanzar las Coronas más poderosas." ${ }^{30}$

Moreover, similarly to what could be verified in the case of Catherine of Braganza's 1661 journey, on their way to the Pheasant Island, lasting over one month, the Spanish-French royal couple paid visit to a number of convents and attended various concerts, comedy plays, masques and bullfights.

Furthermore, the Spanish princess' wedding took place in two stages: while the first religious ceremony, held on 3rd of June in a church in Fuenterrabía was organized by the Spanish, the second one, taking place on 9th of June in a church sited in Saint-Jean-de-Luz, was conducted by the French. In between these two events, on 6th of June, there was an official ceremony that consisted in a protocolary giving away of the bride and a solemn oath to the Treaty of the Pyrenees. The event was held in a wooden cabin built especially for the occasion and featuring two distinct sections: one destined for the French and the other for the Spanish Crowns. The well-known painter Diego

${ }^{27}$ Macedo, 1662: 32.

${ }_{28}$ Our research also involved the analysis of the wedding between Henrietta Maria of France and Charles I of England, as well as the festivities associated with the English Restoration during the reign of Charles II. Both events proved to be of utmost importance for the comprehension of theoretic and iconographical influences behind the Portuguese festivities. Flor, 2012: 113-142.

${ }^{29}$ In his study, Colomer makes reference not only to the royal family but also to the Prime Minister's (Don Luis Mendez de Haro) entourage, which included over 200 people, hundreds of servants, 5000 horseback soldiers, 1500 infantry soldiers, 32 wagons, 18 royal carriages, etc. Colomer, 2003: 62. See also Rio Barredo, 1997.

30 "a royal matrimony that, once again, joined the powerful Crowns" Colomer, 2003: 66. 
Velázquez carried out the decoration of the Spanish part of the cabin, with the assistance of Juan Bautista Martínez del Mazo and José Nieto, who used tapestries from the royal collections ${ }^{31}$.

In Portugal, by the same token, the tapestries were also part of the pro-Restoration discourse promoted by the House of Braganza. Indeed, on the day of his official arrival to Lisbon, during an audience at the Ribeira Palace, Ambassador Extraordinary Edward Montagu was greeted in "gran sala del Fuerte, la mayor, y más hermosa que se sabe, tapisada com la excelente tapiceria de la Tomada de Tunes, y com otras que querian igualarla." ${ }^{32}$ The tapestries also played an important historical and political role during Catherine's departure from the Ribeira Palace. In fact, as reported by Tojal, on her way out the Queen: "crossed majestic halls, with beautiful cloths and canvas in exquisite colours, depicting the martial fables of vain goddesses."${ }^{133}$

Additionally, to commemorate Maria Theresa's arrival to Paris on 26th of August 1660, a series of triumphal arches was erected. Though they were generally described as magnificent, Haro dismissed them as scarce and of poor quality (pocos y no ricos). Significantly enough, in 1662 the Portuguese Crown adopted a very similar model, as these architectural structures were used in order to reinforce the pro-Restoration discourse, by means of both religious (e.g., the statue of St. George) and secular (e.g., royal portraits) images.

Another similarity worth mentioning has to do with the iconography produced to commemorate the Franco-Spanish wedding. Indeed, the aforementioned oath to the Treaty of the Pyrenees (taken on 6th of June) was represented in an oil painting by Adam Frans van der Meulen (a Dutch disciple of Pieter Snayers active in Brussels), who based himself on Charles Le Brun's drawings. Curiously enough, similarly to what happened in the case of Dirck van der Stoop, van der Meulen became most famous as a battle-scene painter ${ }^{34}$.

In the same way, while Jean Mauger produced medallions commemorating the marriage between the House of Austria and the House of Bourbon, Jan, Joseph and Philip Roettiers (a celebrated family of engravers working for the London Mint) or George Bower produced similar models in England, the only difference being that the latter featured images of Charles II and Catherine of Braganza (instead of Louis XIV and Maria Theresa, respectively).

Adding to this, it seems worthwhile to mention the likeness between the two royal monograms: similarly to the monogram adopted by the English monarchs, the motif used by the Franco-Spanish couple featured interwoven letters "M" and "L", topped with a crown ${ }^{35}$.

Finally, in order to conclude this succinct analysis of the Spanish wedding festivities, it should also be stressed that the tapestries, engravings, chronicles and medallions produced for this occasion, as wells as the luxury boasted by the House of Austria, were in fact instruments of propaganda. On the one hand, they served as a token of peace and concord; on the other, they meant to counter the Bourbon Dynasty's pan-European campaign, intended to showcase the weakness of the Spanish monarchy (la flaqueza de la Monarquía Hispánica ${ }^{36}$.

In this light, it seems possible to suggest that, also in this case, the Portuguese Crown followed the Spanish model and recreated some of the circumstances related to the Franco-Spanish royal

\footnotetext{
${ }^{31}$ Checa Cremades, 2003: 21-22.

32 "In a grand hall of the fort, to my knowledge the largest and most beautiful that there is, carpeted with an excellent tapestry depicting the siege of Tunis, as well as other pieces trying to match its beauty." Macedo, 1662: 29.

${ }^{33}$ Tojal, 1716: 86 .

${ }^{34}$ The painting in question serves as a source of inspiration for the tapestry series on the "History of the King", produced in 1665 by Manufacture Royal des Gobelins. Colomer, 2003: 73.

${ }^{35}$ Cf. Empreza dedicada as Magestades de Carlos \& Catherina digníssimos monarchas e poderozissimos Reys da gram Bretanha: no segundo dia dos touros, em que o Conde da Torre celebra o mais fausto de Portugal e o mais felice de Inglaterra. Biblioteca Nacional de Portugal, Secção de Reservados, Cód. 589.

${ }^{36}$ Colomer, 2003: 80-81.
}

Arch. esp. arte, LXXXVIII, 350, ABRIL-JUNIO 2015, 141-156

ISSN: 0004-0428, eISSN: 1988-8511, doi: 10.3989/aearte.2015.09 
wedding. However, in the case of Portugal, they were used in a pro-Restoration discourse, with a view to countering Philip IV's hegemony. In this context, especial emphasis should, once again, be given to the role played by António de Sousa Macedo, Secretary of Internal Affairs (as was, in fact, the case of Leonardo Castillo) and, according to the Relacion de las Fiestas, the spokesman for the 1662 celebrations. Indeed, the abovementioned work is filled with excerpts denoting an anti-Spanish propaganda discourse.

In the first place, the choice of Spanish language in an account of a Portuguese event, though understandable in the light of the 60-year dual monarchy, made it possible for the news on the grandiosity of the wedding ceremony to reach the Spanish public in a more direct and thus more efficient manner: The reasoning behind this choice is overtly stated by the author, as is clear from the following quotation: "es conueniente hazer rellacion dellas, para comunicarlas a los amigos absentes, y para mostrar a todos, que no se ha faltado a lo que se deuia." ${ }^{37}$

In fact, there are numerous hyperboles praising the Portuguese culture: for instance, Terreiro do Paço is described as "the largest and the best square that a Palace or a European city could boast; (...) there is not doubt that it outdid the Roman amphitheatre. ${ }^{.38}$ Numerous references are also made to the abundance of street decorations and to the magnificence of the Portuguese overseas empire (particularly visible in the allegorical parades).

The aforementioned observation is also corroborated by the descriptions of bull-fighting spectacles. Indeed, this typically Spanish tradition is shown as inferior to the Portuguese bull-fighting spectacles organized in October 1661: "This was the end of the bull-fighting festivities, celebrated in Spain but here organized with the greatest perfection and grandeur; let me add that during these three days the costs spent on the exquisite decorations were beyond description and, as a result, can only be imagined." 39

Every so often, the author resorts to veiled threats, for instance when describing Count of Torre's prowess during the bull-fighting spectacle or the demonstration of power of the Portuguese army: "e notese que celebrò Portugal este casamiento, com tan grande dote, solennid, y despesa tan grande e el mismo tiempo, que tienne en campaña contra Castilla três poderosos Exercitos en três Prouincias diferentes (de más de las guraniciones de la otras dós Prouincias) uno en Alentejo, outro en Entre Duero y Mino, outro en la Beyra, quando el Castellano para celebrar el de Francia, fue forçado abstenerse de la guerra contra Portugal. Todo sea para gloria de Dios." ${ }^{40}$

Also noticeable throughout the text is the exaltation of the power of the Portuguese Crown, especially expressed towards Luisa de Guzmán, to whose rule we owe this gift, (cuya Regencia les grangeó este bien), that is, the Anglo-Portuguese alliance, so enthusiastically celebrated by the cheering crowds ${ }^{41}$.

In the final parts annexed to the text in question, the signing of the treaty is associated with an effective victory, resulting from the Anglo-Portuguese union, namely the Battle of Ameixial, fought on 8th June 1663 and represented in one of Dirck Stoop's engravings (commissioned in the very same year by the Queen of England) ${ }^{42}$ (fig. 10).

\footnotetext{
37 "it is important to recount these events, to communicate them to our friends who were absent, and to let everyone know that we did not lack for anything." Macedo, 1662: fl. 21v.

${ }^{38}$ Macedo, 1662: 26

${ }^{39}$ Macedo, 1662: 26

40 "It should be noted that Portugal celebrated this wedding skilfully and solemnly and, at the very same time, led a campaign against Castile with the aid of three powerful armies in three different provinces: one in Alentejo, one in Entre Douro and Minho and one in Beira. The Spanish, for their part, in order to celebrate the Franco-Spanish weeding, were forced to suspend their war against Portugal. All this to the glory of God." Macedo, 1662: 32v.

${ }^{41}$ Macedo, 1662: 22.

${ }^{42}$ The engraving is entitled "Entrada do Exército del Rey de Castella, governado por D. João de Áustria, no Reino de Portugal, com sete mil cavalos e vinte pessas de artilharia."
}

Arch. esp. arte, LXXXVIII, 350, ABRIL-JUNIO 2015, 141-156 ISSN: 0004-0428, eISSN: 1988-8511, doi: 10.3989/aearte.2015.09 


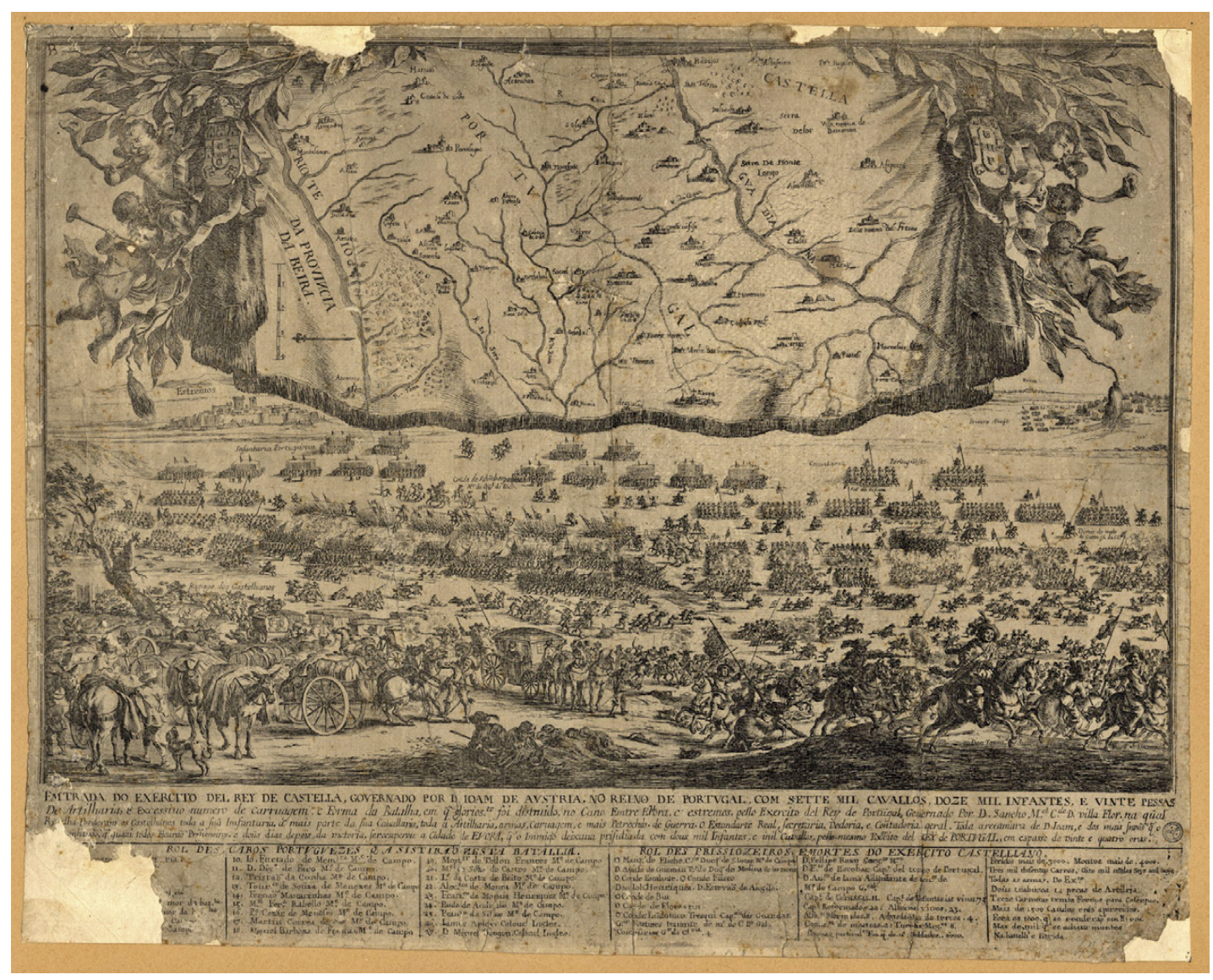

Fig. 10. Dirck Stoop, Battle of Ameixial, 1663, Biblioteca Nacional de Portugal.

\section{Conclusions}

It should thus be clear from the above that, apart from serving as a simple account of the wedding ceremonies of the English royal couple, the Relacion de las Fiestas also portrays these events as an expression of the exaltation of the political unity, namely by referring to specific examples of the Restoration Battles, to some of the Portuguese key historical figures and to the Overseas Empire ${ }^{43}$.

The exaltation of the Portuguese nation's political unity gains even greater dimension and importance if we consider the dissemination of the text now under study (fig. 11). Throughout the text one can find a number of passages pointing to the possibility of future publication, which further justifies the preference given to Spanish language: "que no puede llegar la imaginacion a lo que logro la vista; no cabe en papel relacion más particular, un largo libro puede hazerse de lo que alli se contenia."

\footnotetext{
43 Bouza Álvarez, 1996:12.

44 "Imagination cannot do justice to what we have seen; a piece of paper does not suffice to contain a detailed recount, so a larger book is needed." Macedo, 1662: 30v.
}

Arch. esp. arte, LXXXVIII, 350, ABRIL-JUNIO 2015, 141-156 ISSN: 0004-0428, eISSN: 1988-8511, doi: 10.3989/aearte.2015.09 


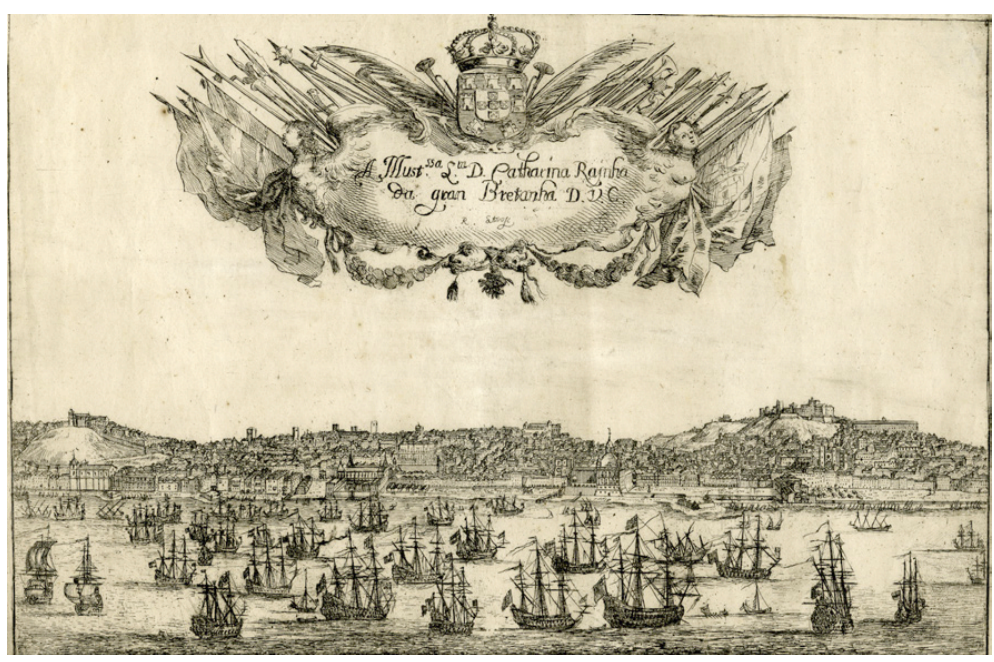

Fig. 11. Dirck Stoop, View of Lisbon from the Tagus, 1662, Museu da Cidade (Lisboa).

As a result, the existence of eight texts published in Portugal and recounting the events related to Catherine of Braganza's wedding (from the way in which the Anglo-Portuguese alliance had been formed to prose description of matrimonial festivities) lends itself to the hypothesis that Stoop's iconographic material had been meant to be part of a publication of greater dimensions ${ }^{45}$. The existence of engravings that accompany the text serves as a good indicator of the "need for using the printed image as a historical source" 46 . It also shows that the Portuguese Crown followed the example of prominent European monarchies which had their (land and naval) battles portrayed by battle-scene artists.

These examples support Bouza Alvarez' claim that: “in modern times the pictorial and visual forms of communication had been granted a full significance and, for this reason, had been used for the purpose of comprehension, expression and recording. (...) Thus, the modern times witnessed the emergence of a new type of spectator, whose relation with the observed object not only does not necessarily involve a physical presence, but also makes it possible for these images to be recovered and revisited time and time again"47 (fig. 12).

${ }^{45}$ Father Sebastião da Fonseca published three more texts in England, including. "Relaçam da forma com que A Magestade del Rey da Grão Bretanha, manifestou a Seus Reynos, tinha ajustado seu casamento, com a Serenissima Infante de Portugal, a senhora Dona Catherina", "Relacion de las Fiestas que se hizieron en Lisboa Con la nueua del casamiento de la Serenissima Infanta de Portugal Dona Catalina (ya Reyna de la Gran Bretana) con el Serenissimo Rey de la Gran Bretana Carlos Segvndo deste nombre, Y todo lo que sucedió hasta embarcarse para Inglatierra", "Festas Reays na côrte de Lisboa, Ao feliz Cazamento dos Revs da graõ Bretanha Carlos, \& Catherína. Em os, Touros que se correram no Terreiro do Passo em Outubro de 1661. Dedicadas a Evropa Prínceza de Phenicia. E Escrítas Por Izandro, Aonio, e Luzindo, Toureiros de forcado", "Quarto dia do Triunfo dos Animais escrito por Berardo Companheiro da Bandeirinha", "Relaçam diaria da jornada que a Serenissima Rainha da Gram-Bretanha D. Catherina fez de Lisboa a Londres indo já desposada com Carlos IJ. Rey daqvelle Reyno e das Festa, que nelle se fizeraõ até entrar em seu Palacio, Lisboa, "Relaçam da chegada Del Rey a Portsmout, \& do que nella se tem passado até Domingo 26 de Junho de 1662", "Relaçam da Sahida de Portsmout atè o Palacio da Quinta de Hanptamcurt", "Relaçam da Entrada de Suas Magestades em Londres, sahindo do Palacio de Hanptamcourt, em tres de Settembro de 1662", "Relaçam dedicada A Serenissima Senhora Rainha da Gran Bretanha da Iornada que fes de Lixboa athe Portsmouth pelo P. Sebastião da Fonseca ...", "Relaçam dedicada as Magestades de Carlos e Catherina Reys da Gran Bretanha da Jornada que fiserão de Porthsmouth the Antoncourt e entrada de Londres pelo P. Sebastião da Fonseca", e "Relaçam das festas de Palacio e grandesas de Londres dedicada A Magestade da Serenissima Rainha da Gran Bretanha pelo P. Sebastião da Fonseca...".

${ }^{46}$ Faria, 2009: 381. 
To conclude, it seems useful to quote the following excerpt from Martim Correia da Silva's correspondence to Pedro Fernandes Monteiro, dating from 24th of August 1661: "We shall all be thankful to God for the wedding of Her Serenity Queen of England, thanks to which we shall be protected, by having such a powerful ally, not only against the Spanish power but also against any other enemy, hopefully bringing great joy to Portugal" 48 .

\section{BIBLIOGRAPHY}

Anderson, R. C. (1929): The journal of Edward Montagu first Earl of Sandwich, Admiral and General at Sea 1659-1665. Navy Record Society.

Borges, Nelson Correia (1986): A Arte nas Festas do Casamento de D. Pedro II. Coimbra: Paisagem Editora.

Bouza Álvarez, Fernando (1996): “"Amor Parat Regna» Memória Visual dos Afectos na Política Barroca”. En: Xavier, Ângela Barreto; Cardim, Pedro y Bouza Álvarez, Fernando: Festas que se fizeram pelo Casamento do Rei D. Afonso VI. Lisboa: Quetzal Editores, pp. 7-26.

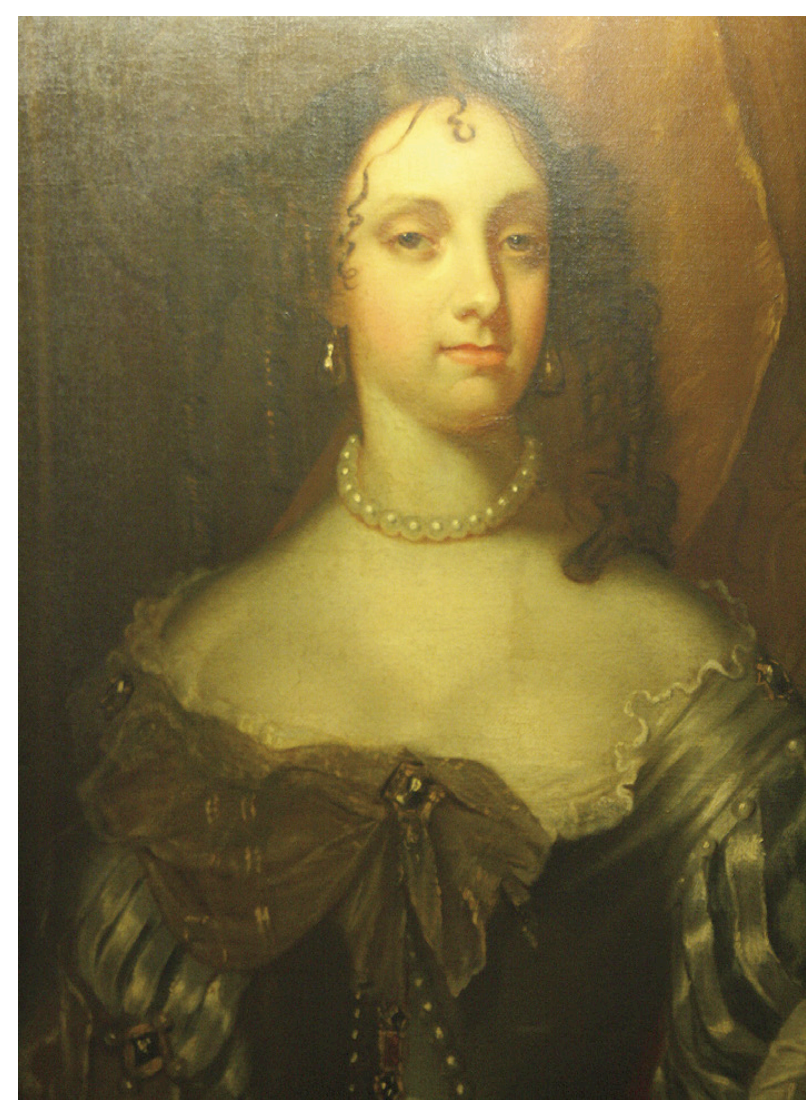

Fig. 12. Jacob Huysmans attrib., Portrait of Catherine of Braganza, c. 1665, Universidade Autónoma de Lisboa.

Brasão, Eduardo (1939): “O protocolo da Partida de D. Catarina de Bragança para a Inglaterra". En: Ocidente. ${ }^{\circ}$ 15, Lisboa: pp. 269-286.

Cabral, Frei António Lopes (1661?): Quarto dia do Triumpho dos Animais escrito por Berardo companheiro da Bandeirinha. Lisboa: Domingos Carneiro.

Cabral, Frei António Lopes (1661): Festas Reays na côrte de Lisboa, Ao feliz Cazamento dos Revs da graõ Bretanha Carlos, \& Catherína. Em os, Touros que se correram no Terreiro do Passo em Outubro de 1661. Dedicadas a Evropa Prínceza de Phenicia. E Escritas Por Izandro, Aonio, e Luzindo, Toureiros de forcado.

Cardim, Pedro (2008): "Una Restauração visual? Câmbio dinástico y uso de las imágenes en el Portugal del siglo XVII". En: Palos, Joan Lluís y Carrió-Invernizzi, Diana: La História Imaginada: Construcciones visuales del passado en la Edad Moderna. Madrid: CEEH, pp. 185-206.

Casimiro, Augusto (1956): Dona Catarina de Bragança-Rainha de Inglaterra, filha de Portugal. Fundação da Casa de Bragança, Portugália Editora.

Castel-Branco, Maria da Conceição (2004): A melhor Jóia da Coroa: Representações de D. Catarina de Bragança na Literatura Inglesa, II vols, Unpublished PhD dissertation, Faculdade de Ciências Sociais e Humanas da Universidade Nova de Lisboa, Lisboa.

\footnotetext{
${ }^{47}$ Bouza Álvarez, 1996: 17-19.

${ }^{48}$ Carta de Martim Correia da Silva para D. Pedro Fernandes Monteiro, Biblioteca da Ajuda, Ms 51-IX-1, 24 de Agosto de 1661, fl.206-207.
}

Arch. esp. arte, LXXXVIII, 350, ABRIL-JUNIO 2015, 141-156

ISSN: 0004-0428, eISSN: 1988-8511, doi: 10.3989/aearte.2015.09 
Checa Cremades, Fernando (2003): "Del gusto de las naciones". En: Checa Cremades, Fernando (ed.): Cortes del Barroco de Bernini y Velazquez a Luca Giordano. Madrid: pp. 17-34.

Colomer, José Luis (2003): "Paz politica, rivalidad suntuari. Francia y España en la Isla dos Faisanes". En: Arte e Diplomacia de la Monarquia Hispânica en el siglo XVIr'. Madrid: Ed. Fernando Vilaverde, pp. 61-88.

Costa, Mário (1956): "Festa do Casamento da Infanta D. Catarina de Bragança com Carlos de Inglaterra". En Olisipo. ano XIX, n ${ }^{\circ} 73$, Lisboa: pp. 3-7.

D. Catarina de Bragança e o Paço da Rainha - Edição Comemorativa (2005). Lisboa: Academia Militar.

Davidson, Lillias Campbell (1908): Catherine of Braganza Infanta of Portugal \& Queen-consort of England. London.

Faria, Miguel Figueira de (2009): “A Colecção de retratos de Diogo Barbosa Machado”. En: Artis- Revista do Instituto de História da Arte da Faculdade de Letras da Universidade de Lisboa. n ${ }^{0} 7-8$, Lisboa: Instituto de História da Arte da Faculdade de Letras da Universidade de Lisboa, pp. 361-384.

Flor, Susana Varela (2012): «Aurum Reginae or Queen-Gold»: Retratos de D. Catarina de Bragança entre Portugal e a Inglaterra de Seiscentos. Fundação da Casa de Bragança.

Lourenço, Maria Paula Marçal (1999): Casa, Corte e Património das Rainhas de Portugal (1640-1754) Poderes, Instituições e Relações Sociais. Vol.I, Unpublished PhD dissertation. Faculdade de Letras da Universidade de Lisboa.

Macedo, António de Sousa de (1662): Relacion de las fiestas que se hizieron en Lisboa, con la nueva del casamiento de la Serenissima Infanta de Portugal Doña Catalina (ya Reyna de la Gran Bretaña,) con el Serenissimo Rey de la Gran Bretaña Carlos Segundo deste nombre: y todo lo que sucedió hasta embarcarse para Inglatierra. Lisboa: Oficina de Henrique Valente de Oliveira.

Macedo (Aonio), António de Sousa de (1661): Festas Reays na Corte de Lisboa ao Feliz cazamento dos reys da grãoBretanha Carlos \& Catherina em os Touros eu se correram no Terreiro do Passo em Outubro de 1661 dedicadas a Europa princeza de Phenicia e escritas por Izandro, Aonio e Luzindo toureiros de forcado, em Lisboa, por Domingos Carneiro.

Mackay, Janet (1937): Catherine of Braganza. London: John Long.

Oliveira, Eduardo Freire de (1893): Elementos para a História do Município de Lisboa. Part 1, Volume VI. Lisboa.

Prestage, Edgar (1914): D. Francisco Manuel de Melo. Coimbra: Imprensa da Universidade de Coimbra.

Rau, Virgínia (1962): "No tricentenário do casamento anglo-português de 1662". En: Sep. do Arquivo de Bibliografia Portuguesa. Coimbra, ano VII: 27-28.

Rau, Virgínia (1941): “D. Catarina de Bragança - Rainha de Inglaterra”. En: O Instituto. Vol. 98, Coimbra: 5-330.

Rio Barredo, Maria José del (1997): Fiestas públicas en Madrid: 1561-1808. Madrid: UAM.

Santarém, Visconde (1842-69): Quadro elementar das relações diplomáticas de Portugal com as diversas potências do mundo desde o princípio da monarquia portuguesa até aos nossos dias. 18 vols. Paris: J. P. Aillaud.

Soares, Ernesto (1954): Dicionário de Iconografia Portuguesa. Suplemento, Lisboa: Instituto de Alta Cultura.

Sousa, António Caetano de (2007): "Da Infanta D. Catharina, Rainha da Grãa Bretanha” in História Genealógica da Casa Real Portuguesa. vol. VII, Ed. QuidNovi/Público, Academia Portuguesa de História, [1735-49].

Sousa, Manuel Andrade e (1994): Dona Catarina, Infanta de Portugal; Rainha de Inglaterra. Lisboa: Edições Inapa.

Strickland, Agnes (1845): “Catherine of Braganza”. En: Lives of the Queens of England from the Norman Conquest; with Anecdotes of their courts. Vol. VIII, London: Henry Colburn Publisher, 1845, pp. 267-478.

Tojal, Pedro de Azevedo (1716): Carlos Reduzido. Inglaterra Ilustrada. Poema heroico oferecido à soberana majestade del Rei N.S. D. João V... Lisboa: António Pedro Galram.

Troni, Joana de Almeida (2008): Catarina de Bragança (1638-1705). Lisboa: Edições Colibri.

Vidal, Frederico Gavazzo Perry (1940): "O casamento de D. Catarina de Bragança com Carlos II, Rei de Inglaterra- notas e algumas gravuras que ao facto se referem”. En Revista dos Centenários, pp. 1-7.

Fecha de recepción: 13-II-2014

Fecha de aceptación: 18-VI-2014

Arch. esp. arte, LXXXVIII, 350, ABRIL-JUNIO 2015, 141-156 ISSN: 0004-0428, eISSN: 1988-8511, doi: 10.3989/aearte.2015.09 